\title{
ANALYSIS OF BI-COLD FORMED STEEL CONCRETE COMPOSITE BEAMS
}

\author{
L. M. Abdel Hafez \\ Associate Professor, Civil Engineering Department, Faculty of \\ Engineering, Minia University, Minia, Egypt
}

(Received January 24, 2006 Accepted February 7, 2006)

\begin{abstract}
This paper presents the numerical study to simulate the behavior of cold-formed bi-steel-concrete beams using ANSYS program. The study was carried out on fifteen beams having six steel plate shapes of $10 \mathrm{~mm}$ thickness tested experimentally by Ahmed [1]. The composite action between steel and concrete was insured using steel connectors in form of nails fixed through drilled holes in steel plate by means of epoxy. The main parameters considered in this analysis were the steel plate's shape and the position of the connectors. Also this study was extended to study some parameters didn't take into account experimentally such as the effect of concrete strength and nail diameter
\end{abstract}

KEY WORDS : Bi-Cold Formed steel Concrete Composite Beams, Finite Element Modeling

\section{1- INTRODUCTIOIN}

Modeling the complex behavior of different types of composite beams is an interest task in finite element analysis. Only recently have researchers [2-10] attempted to simulate the behavior of $\mathrm{T}$ beam in which a steel section, either box or I section is connected to concrete slab in such a way that ensures the composite action between them or incasing steel section in concrete. They considered different parameters such as type of shear connectors, influence of slab profile shear connection on the behavior of beam, slips at the steel beam concrete slab interface, effect of repeated load on the slips of connection and the used of high strength concrete.

This paper presents the numerical study to simulate the behavior of profiled trough beams. The software package ANSYS was used for this study. For the purpose of comparison, the study was carried out on fifteen cold-formed bi-steel concrete composite beams were experimentally tested and reported by Ahmed [1]. Six steel sheet shapes, named shape I, II, III IV and VI were used in his experiment work. Details of these shapes are given in text [1]. The composite action between steel plates and concrete was ensured using steel connectors in the form of nails fixed drilled holes in steel plate by means of epoxy. Different shear connectors (nails) arrangements were considered for different beams. The load deflection and load steel strain plots and type of failure for the above cases obtained from numerical study were compared with those reported experimentally. The study was extended to cover some parameters didn't take into account experimentally such as the effect of concrete strength and nail diameter. 


\section{2- GEOMETRY AND MATERIAL PROPERTIES}

The geometry and the material prosperities as reported by Ahmed [1] were used in this study. Fifteen bi-cold-formed steel concrete beams of Ahmed's experimental testing program (Group A) were analyzed. These beams having steel plate thickness of $1.0 \mathrm{~mm}$ with six different steel sheet shapes and different shear connectors (nails) arrangements. All nails were from high tensile steel and nail length were nearly of $3 \mathrm{~cm}$. The dimensions, the shape of steel plate and the arrangements of nails of different analyzed bi-cold-formed steel concrete beams are shown in Fig. 1. The average yields strength and the ultimate strength of nails and steel plate were $3600 \mathrm{~kg} / \mathrm{cm}^{2}$ and $5200 \mathrm{~kg} / \mathrm{cm}^{2}$, respectively. The average compressive strength of concrete beams was $320 \mathrm{Kg} / \mathrm{cm}^{2}$. The calculated Young's modulus of concrete based on the Egyptian code of Practice [11] and steel were $250499 \mathrm{~kg} / \mathrm{cm}^{2}$ and $2000000 \mathrm{~kg} / \mathrm{cm}^{2}$ respectively. Poison's ratio was assumed as 0.17 for concrete and 0.3 for steel plate and nails. The shear transfer coefficient for open crack and closed crack were considered as 0.3 and 1 , respectively. The calculated concrete tensile strength based on the Egyptian code of Practice [11] was $35 \mathrm{~kg} / \mathrm{cm}^{2}$.

\section{3- NUMERICAL STUDY}

\section{3-1 Finite Elements Idealization}

Finite elements adopted by ANSYS were used. Solid 65 elements were used to model the concrete. The rebar capability of this element was not considered. All nails were modeled using link 8- 3D spar element. Solid 45 elements were used for cold-formed steel sheet and steel plate under the load. Contact elements 52 were used to contact the surface of the cold-formed steel sheet to the surface of the concrete. The bond between steel connector, cold-formed steel sheet and concrete was assumed as perfect and no loss of bond between them was considered in this study. A quarter of the full beam was used for modeling by taking advantage of the symmetry of the beam and loading. Planes of symmetry were required at the internal faces. At a plane of symmetry, the two rotations of this plane and the displacement in the direction perpendicular to that plane were held at zero. The simple support was simulated by zero translations in the direction of the depth and breadth at the bottom of the beam. Also the translation in direction parallel to the support at the top fiber of the web, were held to zero. This type of end condition was aimed to eliminate the effect of membrane actions due to end conditions. A very fine mesh was provided to simulate the geometry of the analyzed models and to satisfy the requirement of the used element's aspect ratio (solid 65 and solid 45). So the finite element model consisting of 2646, 1134, 135 and 832 numbers of solid 65 , solid45, link 8- 3D spar and contact 52, respectively. The numbers of elements of solid 45, link 8 and contact 52 become lesser depends on the steel shape plate and number of nails. Figure 2 shows a typical quarter symmetry finite element model for one of the analyzed models. 

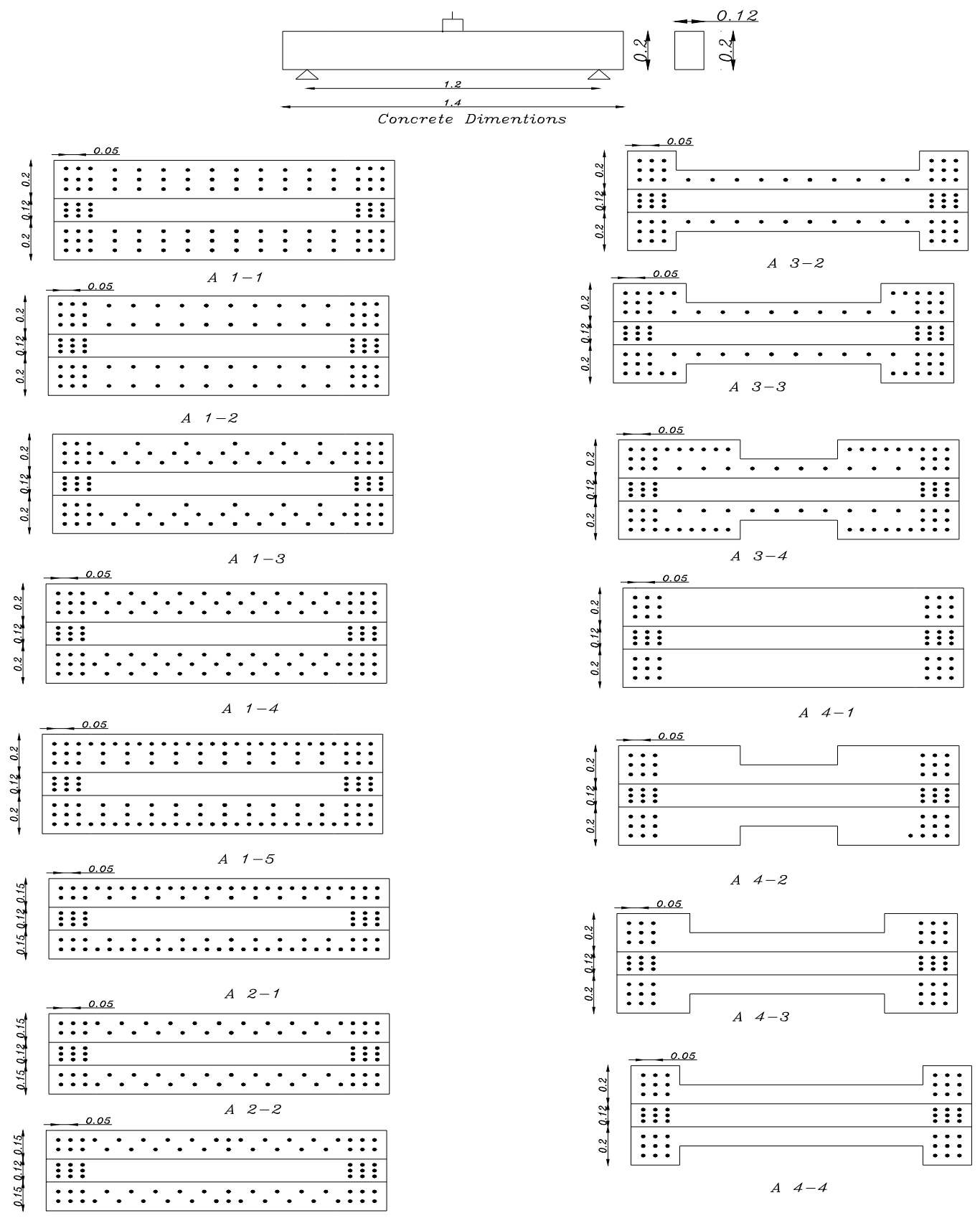

Fig. 1: The shape of steel sheet and the position of nails.

\section{2- Non-Linear Solution and Failure Criteria}

In this study the total load applied was divided in to a series of load increments. Newton RaPhson equilibrium iterations provide convergence at the end of each load increment within tolerance limits. The automatic time stepping in the ANSYS program 
predicts and controls load steep sizes for which maximum and minimum load step sizes are required [12]. The finer increments were used to ensure that the cracking and failure loads could be predicted with $2 \%$ since failure was expected within that range. In this analysis the convergence tolerance was taken at 0.01 of displacement with maximum iteration number of 40 , to reduce the accumulation forces within the iteration.

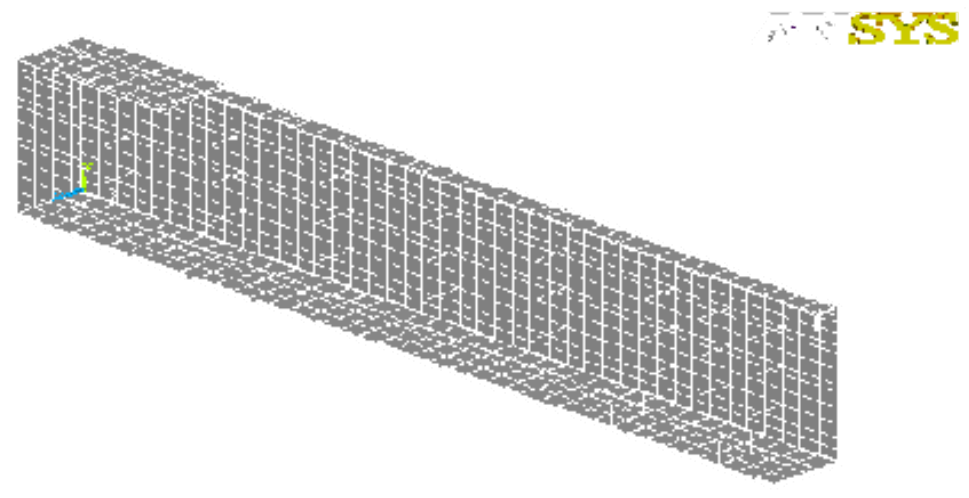

Fig. 2: Quarter symmetry Finite element model mesh.

\section{4-REULTS and DISCUSSION}

Huge amount of output data were obtained from these analyses. However, only typical results of pattern of cracks; buckling of the steel plate and the shape of failure of some composite beams, Load-central Deflection and Load-Maximum tensile steel plate strain of all analyzed beams are given. Table 1 summarizes the results of theoretical analysis and the comparison between the reported experimental results .

\section{4-1 W.R.T Cracking, First Yield, and Ultimate Failure Loads}

(a)First Theoretical Cracking Load: It can be seen form that table; there is a significant effect of the shape of steel plate sheet and the arrangements of connectors a long the span on the theoretical cracking load. The increase in the provided area of steel through the shape of steel plate sheet and the numbers of nails provides extra stiffness to the concrete beam leads to improving cracking load. The experimental cracking load was not reported because the tension side of the concrete beams was covered with steel plate sheet. The ratio of theoretical cracking to theoretical ultimate loads $\left(\mathrm{P}_{\mathrm{cr}} / \mathrm{P}_{\mathrm{ul}}\right)$ was depended on the type of failure of the tested composite beam, as it can be seen from Table 1. The average ratio of theoretical cracking load to theoretical ultimate load for composite beams failed in flexural was 0.24 .

(b) First Theoretical Yield Load: Table 1 shows that; there is a minor effect of shape of steel plate sheet and the arrangement of nails a long the span on the theoretical first yield load for composite beams failed in flexural. It must be mentioned that, all tested beams have same area of steel plate sheet in tension zone. The ratio of 
Table 1: Summary of theoretical results and the comparison with the experimental values.

\begin{tabular}{|c|c|c|c|c|c|c|c|c|c|}
\hline \multirow{3}{*}{$\begin{array}{l}\text { Mode } \\
\text { N0. }\end{array}$} & \multicolumn{3}{|c|}{$\begin{array}{l}\text { Theoretical results } \\
\mathrm{Kg}\end{array}$} & \multicolumn{2}{|c|}{$\frac{\text { theoretical }}{\text { experimental }}$} & \multirow{3}{*}{ Theoretical Type of failure } & \multirow{3}{*}{$\begin{array}{c}\text { Experiment } \\
\text { Type of failure }\end{array}$} & \multicolumn{2}{|c|}{$\begin{array}{l}\text { Theoretical } \\
\text { results }\end{array}$} \\
\hline & \multirow{2}{*}{ 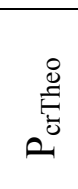 } & \multirow{2}{*}{ 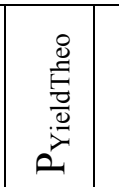 } & \multirow{2}{*}{ } & \multirow{2}{*}{$\frac{P_{\text {yieldthe }}}{P_{\text {yield ex }}}$} & \multirow{2}{*}{$\frac{P_{\text {ultheor }}}{P_{\text {ult exp }}}$} & & & \multirow{2}{*}{$\frac{P_{c r}}{P_{u l t}}$} & \multirow{2}{*}{$\frac{P_{\text {yiel }}}{P_{\text {ult }}}$} \\
\hline & & & & & & & & & \\
\hline \multicolumn{10}{|c|}{ Steel plate shape I } \\
\hline A1.1 & 1950 & 5550 & 7800 & 0.77 & 0.994 & \multirow{5}{*}{$\begin{array}{l}\text { Initiated by yielding of steel and } \\
\text { end by crushing of concrete } \\
\text { causing local buckling of steel } \\
\text { sheet at center of span at top at } \\
\text { extreme compression fibers }\end{array}$} & \multirow{5}{*}{$\begin{array}{l}\text { Same as } \\
\text { theoretical mode } \\
\text { of failure }\end{array}$} & 0.24 & 0.71 \\
\hline A1.2 & 1645 & 5550 & 7800 & 0.77 & 1.02 & & & 0.21 & 0.71 \\
\hline A1.3 & 1500 & 5670 & 7050 & 0.787 & 0.94 & & & 0.24 & 0.8 \\
\hline A1.4 & 1650 & 5550 & 7800 & 0.79 & 1.04 & & & 0.22 & 0.71 \\
\hline A1.5 & 1920 & 5649 & 7200 & 1.027 & 1.015 & & & 0.27 & 0.78 \\
\hline A 4.1 & 1200 & $\begin{array}{l}\text { Not } \\
\text { yield }\end{array}$ & 4355 & --------- & 1.007 & $\begin{array}{c}\text { Local crushing at center at } \\
\text { extreme compression fibers, } \\
\text { followed by local bucking at the } \\
\text { same position }\end{array}$ & $\begin{array}{c}\text { Same as } \\
\begin{array}{c}\text { theoretical mode } \\
\text { of failure }\end{array} \\
\end{array}$ & 0.27 & $\begin{array}{l}\text { Not } \\
\text { yield }\end{array}$ \\
\hline \multicolumn{10}{|c|}{ Steel plate shape II } \\
\hline A2.1 & 1200 & 5800 & 6765 & 0.9 & 1.008 & \multirow{2}{*}{$\begin{array}{l}\text { Same as A1.1 with smaller failure } \\
\text { load }\end{array}$} & \multirow{2}{*}{\begin{tabular}{|c|} 
Same as \\
theoretical mode \\
of failure
\end{tabular}} & 0.18 & 0.86 \\
\hline A2.2 & 1200 & 5800 & 6765 & 0.9 & 1.008 & & & 0.18 & 0.86 \\
\hline \multicolumn{10}{|c|}{ Steel plate shape III } \\
\hline A3.1 & 1380 & 6150 & 6624 & 0.99 & \begin{tabular}{l|l}
1.02 \\
\end{tabular} & & & 0.21 & 1.03 \\
\hline \multicolumn{10}{|c|}{ Steel plate shape IV } \\
\hline$A^{*} 3.2$ & 1600 & 5840 & 6240 & $\begin{array}{l}\text { Not } \\
\text { yield } \\
\text { Exper. }\end{array}$ & 1 & $\begin{array}{l}\text { Same as A1.1 with smaller failure } \\
\text { load }\end{array}$ & $\begin{array}{c}\text { Same as } \\
\text { theoretical mode } \\
\text { of failure }\end{array}$ & 0.25 & 0.93 \\
\hline A 4.4 & 2016 & Not yield & 4416 & --- & 1.09 & $\begin{array}{c}\text { Local crushing of concrete in } \\
\text { compression zone at center } \\
\text { followed by local buckling of steel } \\
\text { plate }\end{array}$ & $\begin{array}{c}\text { Same as } \\
\text { theoretical mode } \\
\text { of failure }\end{array}$ & 0.47 & --- \\
\hline \multicolumn{10}{|c|}{ Steel plate shape V } \\
\hline A 3.3 & 1520 & 5840 & 6320 & 0.9 & 0.93 & $\begin{array}{c}\text { Same as A1.1 with smaller failure } \\
\text { load }\end{array}$ & $\begin{array}{c}\text { Same as } \\
\text { theoretical mode } \\
\text { of failure }\end{array}$ & 0.22 & 0.85 \\
\hline A 4.3 & 1580 & Not yield & 4200 & --- & 1.04 & $\begin{array}{c}\text { Crushing of concrete at center and } \\
\text { local buckling of steel plate in } \\
\text { compression zone }\end{array}$ & $\begin{array}{c}\text { Same as } \\
\text { theoretical mode } \\
\text { of failure }\end{array}$ & 0.4 & --- \\
\hline \multicolumn{10}{|c|}{ Steel plate shape VI } \\
\hline A 3.4 & 1400 & 6000 & 6800 & 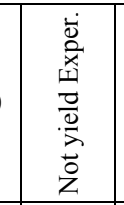 & 1.013 & $\begin{array}{l}\text { Closed to failure load, at center of } \\
\text { the span, steel plate in tension } \\
\text { zone yielded and concrete in } \\
\text { compression zone crushed } \\
\text { followed by local buckling of steel } \\
\text { plate in compression zone } \\
\end{array}$ & $\begin{array}{c}\text { Crushing and } \\
\text { local buckling of } \\
\text { steel sheet in } \\
\text { compression } \\
\text { zone }\end{array}$ & 0.21 & 0.88 \\
\hline A 4.2 & 1360 & Not yield & 4880 & ---- & 1.21 & $\begin{array}{c}\text { Crushing of concrete at center and } \\
\text { local buckling of steel plate in } \\
\text { compression zone }\end{array}$ & $\begin{array}{c}\text { Same as } \\
\text { theoretical mode } \\
\text { of failure }\end{array}$ & 0.33 & ---- \\
\hline
\end{tabular}


theoretical first yield load to the experimental first yield load is $0.78,0.9,0.99,1.02$ of beams (A1.1, A1.2, A1.3, A1.4), (A2.1, A2.2), (A3.1, A3.3) and (A1.5), respectively. Although these composite beams (A1.1, A1.2, A1.3, A1.4) failed in flexural, The theoretical first yield load is smaller than The experiment first yield load that may be due to the strain gauges of these beams did not work adequately.

(C) Theoretical Ultimate Failure Load: The average ratio of theoretical ultimate failure load to the experimental ultimate failure load is 1.0, excluding composite beam number A4.2 that failed at 1.2 of the experimental ultimate failure load. It is noted from these comparisons that the predicted results compare will with experimental results.

\section{4-2 W.R.T Load VS Deflection Curves}

Figures 3 to 17 show the comparisons between the experimental Load-Deflection curves at center of the analyzed composite beams and the corresponding theoretical values. It is noted from these comparisons that the predicted results compare reasonably with experiment excluding composite beams A4-1(Steel plate shape I), A4.2 (Steel plate shape IV) and A4.4 Steel plate shape V) which have Stiffer results. In numerical analysis the compressive uniaxial stress-strain relationship for concrete is required for defining the material non-linearity [12]. However, in this study, the Young's modulus for concrete was considered as a constant value for all ranges of loading for all composite analyzed beams, since the stress-strain history was not reported by Ahmed [1]. Only one value of concrete compressive strength was reported for all analyzed composite beam. All numerical plots in this study show almost linear response.
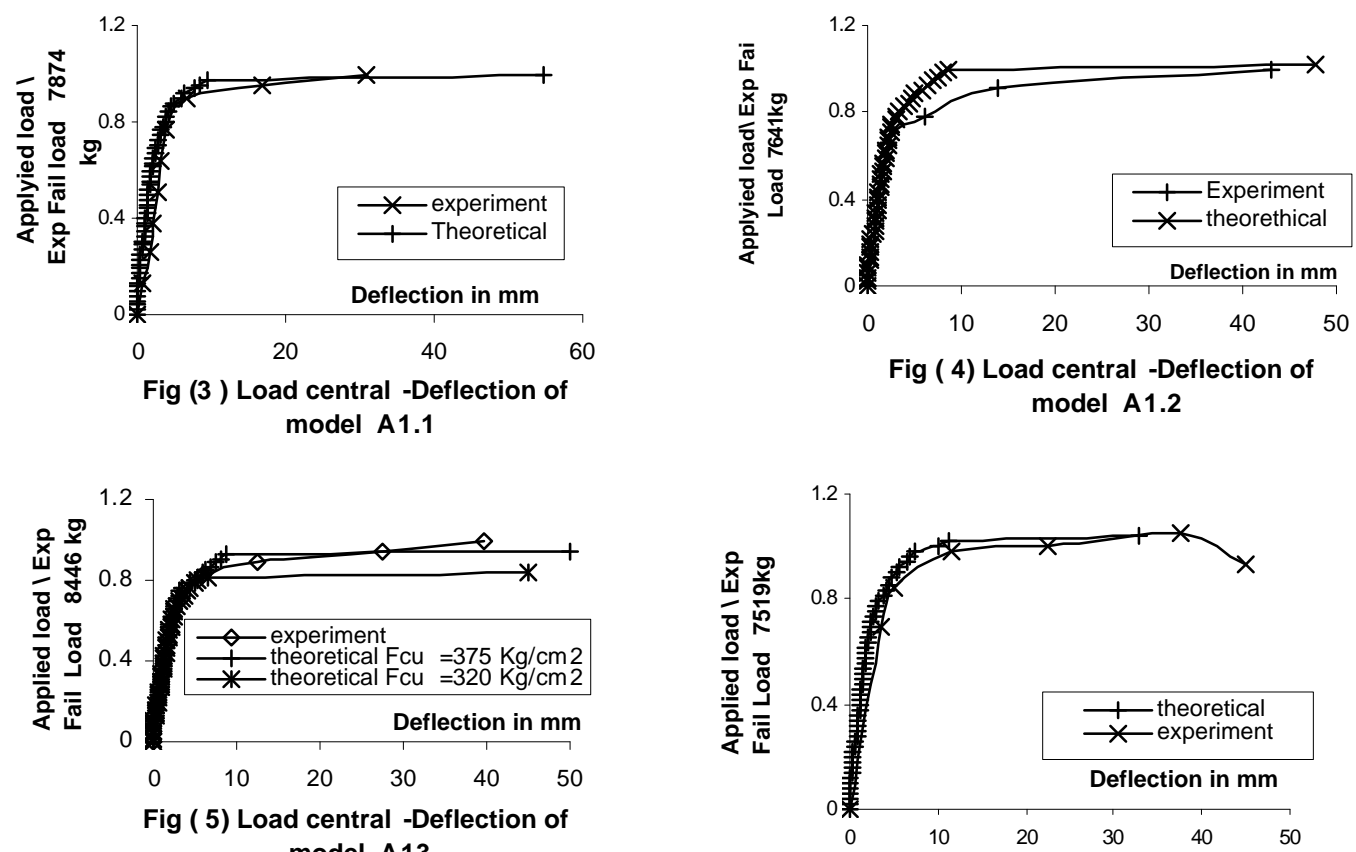

Fig ( 5) Load central -Deflection of model A13

Fig (6 ) Load central -Deflection of model A1.4 


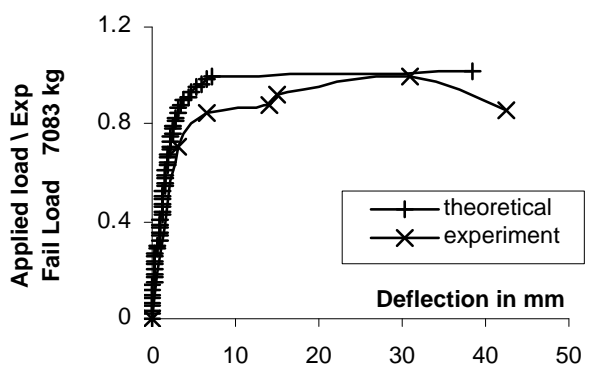

Fig (7) Load central -Deflection of model A1.5

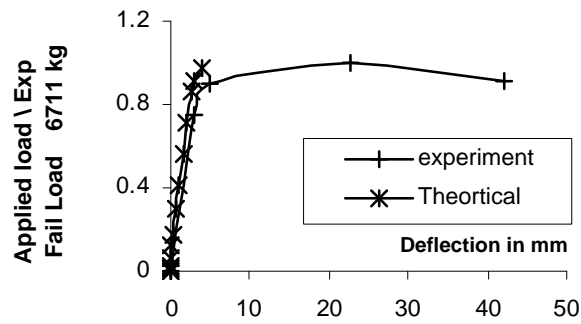

Fig (9) Load central -Deflection of model A2.2

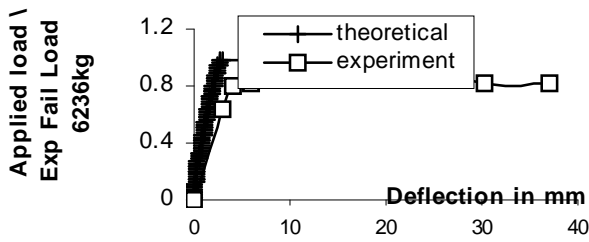

Fig (11 ) Load central -Deflection of model $A 3.2$

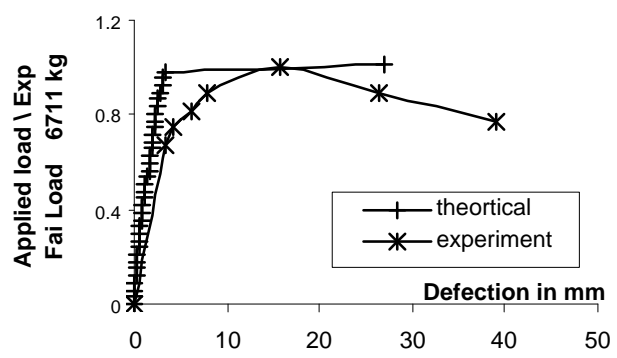

Fig (13) Load central -Deflection of model A3.4

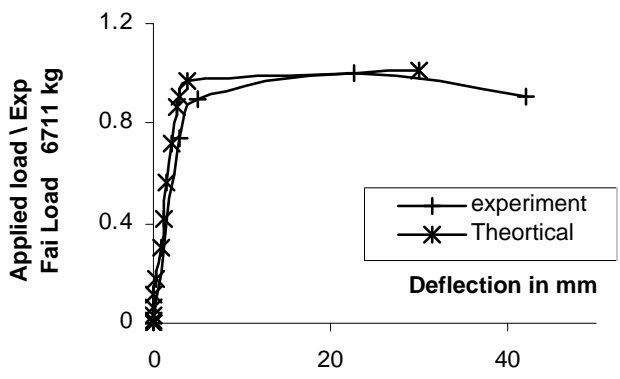

Fig (8) Load central -Deflection of model A2.1
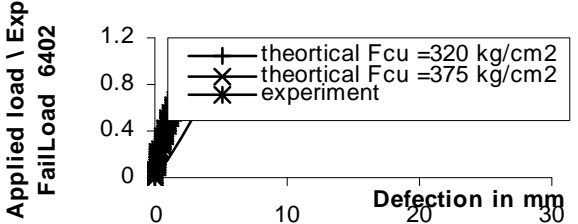

Fig (10) Load central -

Deflection of model A3.1

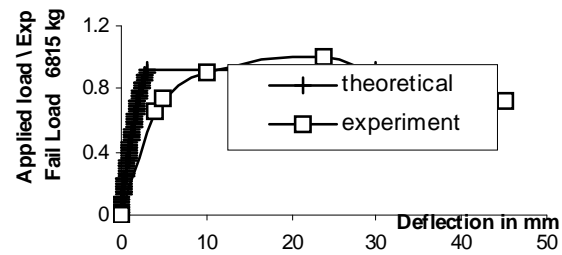

Fig (12) Load central -Deflection of model A3.3
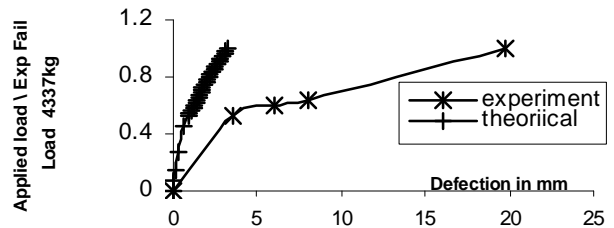

Fig ( 14) Load central -Deflection of model A4.1 

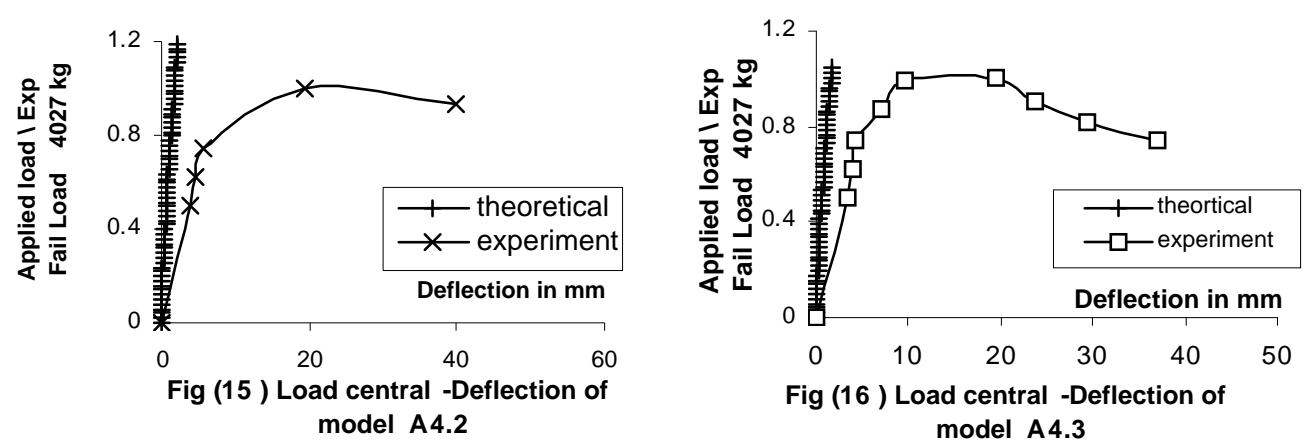

Fig (16) Load central -Deflection of model A4.3

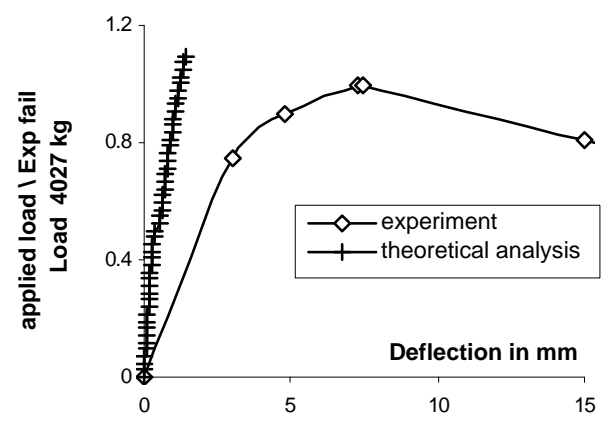

Fig (17) Load central -Deflection of model A4.4

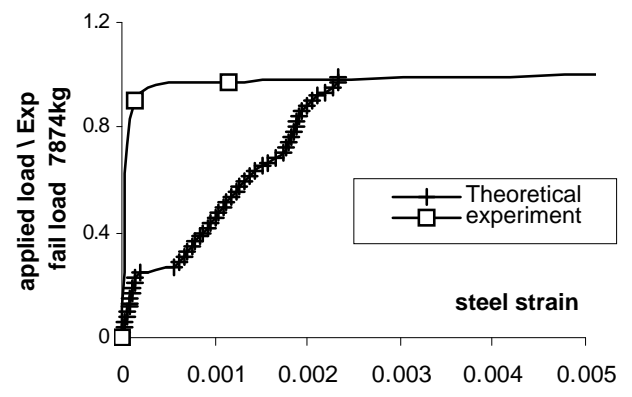

Fig (18) Load central -steel plate of model $A 1,1$

\section{4-3 W.R.T Load VS Steel Plate strain Curves}

Figures 18 to $\mathbf{2 4}$ show the comparisons between the experimental reported Loadcentral steel plate tensile strain curves of the considered composite beams and the corresponding theoretical values. Although there is a good agreement between experimental and the theoretical results for load deflection curves which represent the overall behavior of the analyzed composite beams, It is noted from load central steel plate strain that the predicted results are flexible comparing with corresponding experimental values. The experimental results show that the steel plate sheet in tension side at center carried negligible stresses up to $80 \%$ of the ultimate experimental failure load.

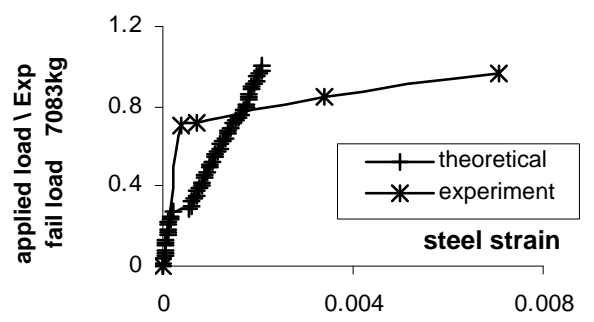

Fig (19) Load central -steel plate of model A1.5

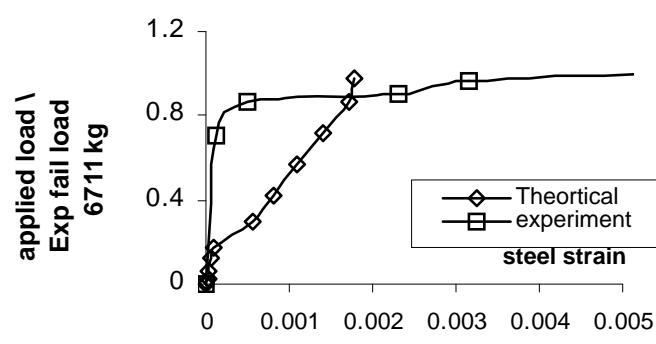

Fig (20) Load central -steel plate of model A2.1 


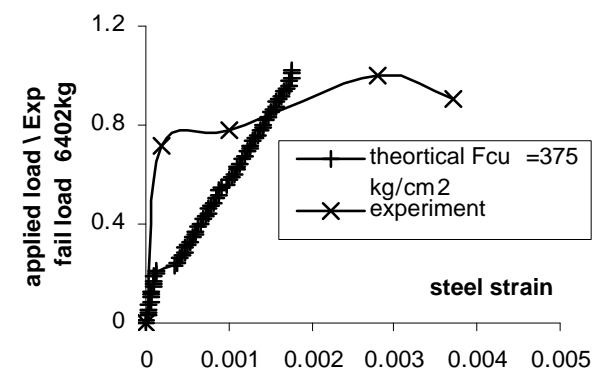

Fig (21) Load central -steel plate of model A3.1

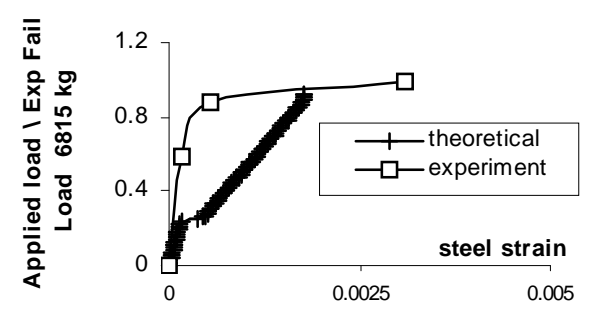

Fig (23) Load central -steel strain of model A3.3

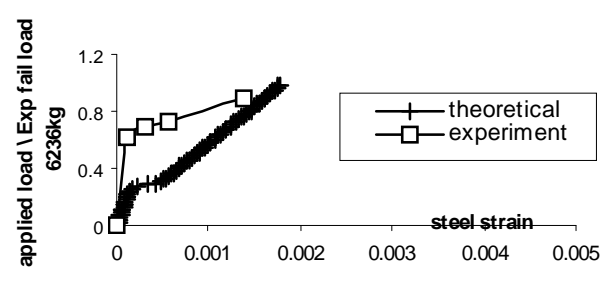

Fig (22) Load central -steel plate of model A3.2

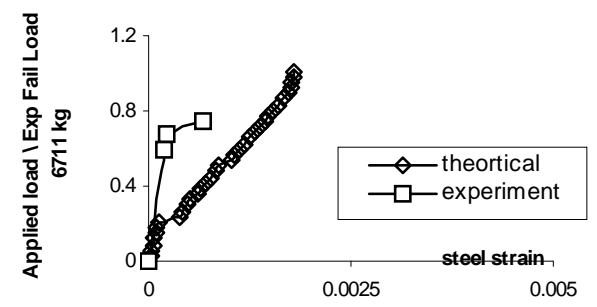

Fig (24) Load central -steel strain of model A3.4

\section{4-4 W.R.T Pattern of Cracks and Mode of Failure}

Figures 25 to 29 show the plots of initial cracking pattern and the finial-deformed shape.

(a) Pattern of cracks: The patterns of cracks for some of analyzed composite beams are given in Fig 25. Table 1 shows the Experimental and the theoretical mode of failure of all analyzed composite beams. It is noted from Fig. 25, that generally the first visible crack was in the form of flexural nature at the tension side especially near the load application for all analyzed composite beams. As the applied load increased, the flexural cracks have been extended upwards to the compression zone. This is the same behavior as reported by Ahmed [1].

(b) Mode of Failure: Two modes of failures were noted in these analyses as shown in Table 1:

(1) Flexural Mode of Failure: This mode of failure is noted in all composite beams, which have nails along the span. It is initiated by yielding of steel and end by crushing of concrete in compression zone causing local buckling of steel sheet at center of span near the extreme compression fibers. This is the same behavior as reported by Ahmed [1]. Also the analysis shows that the horizontal and the short vertical elements of steel plate sheet at top at center distorting in the plane of its cross section, as it can be seen in Fig. 26. 


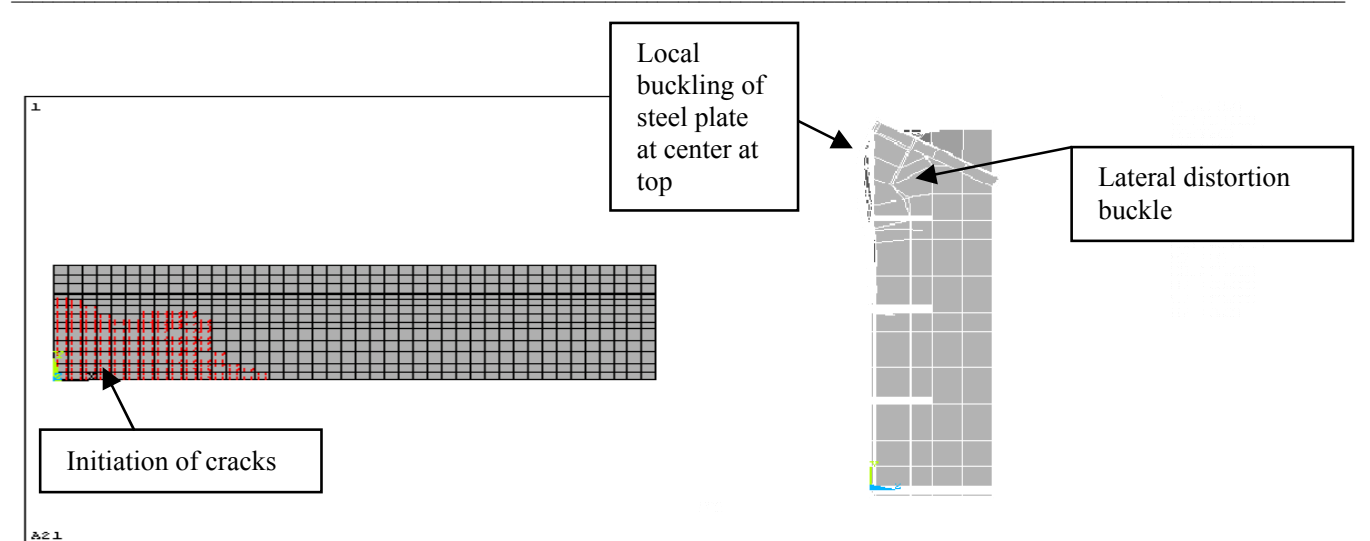

Fig (25) the initiation of cracks at center at tension side of one of tested composite beams

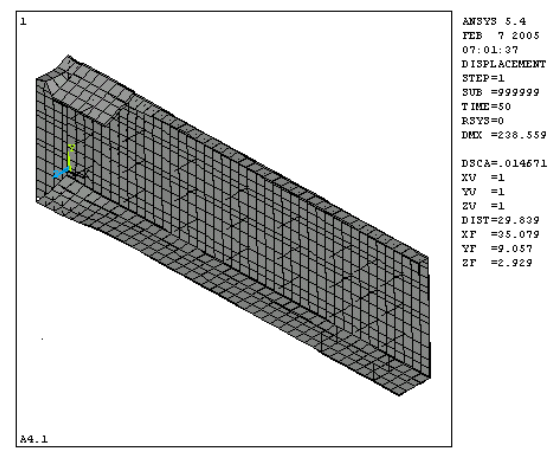

Fig (27) The shape of one of composite beams at failure (fails in flexural (I steel sheet shape with nails along the span))

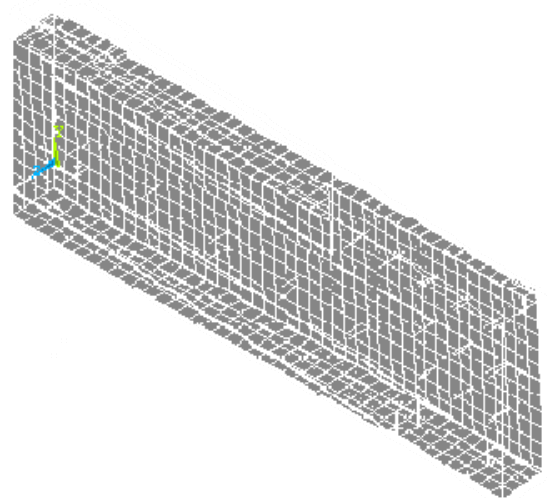

Fig (29) the deformed shape of composite beam A3.2 (nails along the span)
Fig ( 26 ) the deformed cross section at failure of one of analyzed composite beams(I shape with nails along the span) fails in flexural

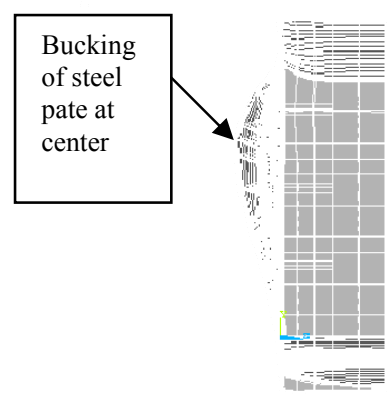

Fig ( 28 ) The deformed cross section at failure of composite beam A4.1 (no nails along the span) ( buckling of steel plate at center) 
(2) Compression Mode of Failure: A sudden failure in compression zone at center of span causing local buckling of steel pate at that position. This mode of failure is noted in composite beam A4.1, which has no nails along the span as it can be seen in Fig. 28.

\section{5- PARAMETERS DID NOT STUDY EXPERIMENTALY}

Composite beam A1.1 is used to study the effect of concrete compressive strength and nail diameter on its overall behavior. Five concrete grads are used, C250, C320, C450, C550 and C650 in this analysis. Also five different diameters of $1 \mathrm{~mm}, 2, \mathrm{~mm}, 3 \mathrm{~mm}, 4 \mathrm{~mm}$, and $5 \mathrm{~mm}$ of connectors are used. C320 was used in these composite beams. Table 2 gives the properties of the used materials

Table 2: The properties of the used materials.

\begin{tabular}{|l|c|c|c|c|c|}
\hline Concrete compressive strength Kg/cm & 250 & 320 & 450 & 550 & 650 \\
\hline Concrete tensile Strength Kg/cm & 30 & 34 & 40 & 44.5 & 48.4 \\
\hline Modulus of elasticity $\mathrm{Kg} / \mathrm{cm}^{2}$ & 221369 & 250499 & 296985 & 328329 & 356383 \\
\hline Fod & &
\end{tabular}

For all analyzed composite beams, Steel yield strength $=3600 \mathrm{Kg} / \mathrm{cm}^{2}$, Ultimate steel strength $=5200 \mathrm{Kg} / \mathrm{cm}^{2} \varepsilon_{\mathrm{y}}=0.0017, \varepsilon_{\text {ult }}=0.009$

\section{5-1-Effect of Concrete Strength}

\section{W.R.T Crack Pattern and Mode of Failure:}

The first visible crack was in the form of flexural nature for all analyzed beams, as it was given in Fig. 25. It was initiated in pure bending zone. As the applied load increased, the flexural cracks extended upwards to the compression zone. Also some cracks initiated under the load applications in the cover of concrete section only. For further application of load increment, many cracks appeared and extended in inclined direction towards the compression zone. At last stages of loading, for this case of study, the topside of the composite beam at center of the span is subjected to excessive compressive stresses. Thus two types of failure were noted in this analysis depended on the used concrete compressive strength:

1- For the composite beams which had low concrete compressive strength (C250, $\mathrm{C} 320$ ), the concrete crushed and the redistribution of the stresses in compressing zone makes the horizontal part of steel pate subjected to excessive compression stress. This part is restrained by the stiffness of the vertical part of steel plate sheet only,. The horizontal element of steel plate at center buckles sideways and twists and the short part of steel plate sheet in vertical direction distorting in the plane of its cross section.. Generally the horizontal element of steel plate is quite stocky so that it displaces and twists as a rigid body during bucking, as it can be seen in Fig. 29.

2- For composite beams that had higher concrete compressive strength (C550, C650), the concrete did not crush but the steel plate sheet in tension zone reached to its ultimate limit strength as it can be seen from Fig. 30 and Fig. 31. 


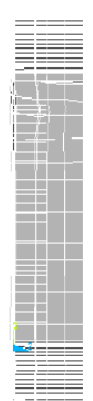

Fig (30) the deformed cross section at failure of the composite beam A1.1 $\left(\mathrm{F}_{\mathrm{cu}}=550 \mathrm{~kg} / \mathrm{cm}^{2}\right)$ fracture of the steel plate at bottom

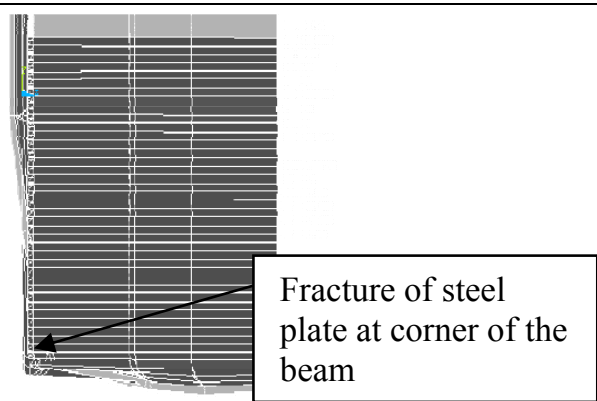

Fig (31) the magnification of the deformation of the bottom side of cross section at failure of the composite beam A1.1 $\left(\mathrm{F}_{\mathrm{cu}}=550 \mathrm{~kg} / \mathrm{cm}^{2}\right.$, fracture of the steel plate at bottom

\section{W. R. T Deflection:}

Load-central deflection curves of the analyzed composite beams of different concrete strength were plotted as shown in Fig. 32. From these curves it can seen that:

- The behavior of the analyzed beams is linear up to certain limit, depending on the grade of the used concrete. As concrete strength increases the linear part of curves slightly lengthened too.

- The curves indicate that the initiation of nonlinearity was different of the analyzed composite beams, depending on the used of concrete grade, as the concrete strength increases, the tensile strength of concrete increases, cracking load increases too. It ranges of 0.17 to 0.0 .305 of the failure load of the control composite beam

- $\quad$ Fig. 32 reflects clearly the effect of concrete compressive strength on the flexural rigidity of the analyzed beams, as the concrete compressive strength increases the flexural rigidity increased too. This was due to the increase of the modulus of elasticity

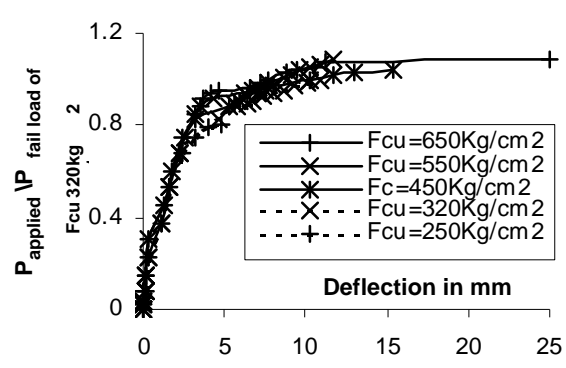

Fig (32) Load central -Deflection of model A1.1 for different concrete strength

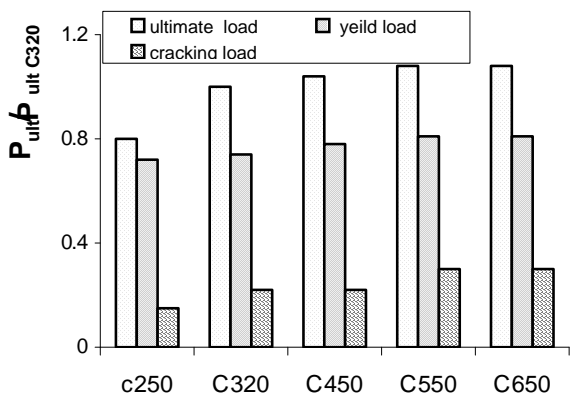

Fig (33) Variation in ultimate, yeild, and cracking loads for versus concrete grades 
W. R. T Concrete Compressive Strains and Steel Tensile Strains:

Load-Maximum compressive concrete strain and Maximum tensile steel plate sheet strain at extreme fibers in longitudinal direction at the center of the analyzed composite beams are given in Fig. 34.

It can be seen from these curves that the general behavior was similar to the overall behavior of the considered composite beams as indicated by load-deflection curves.

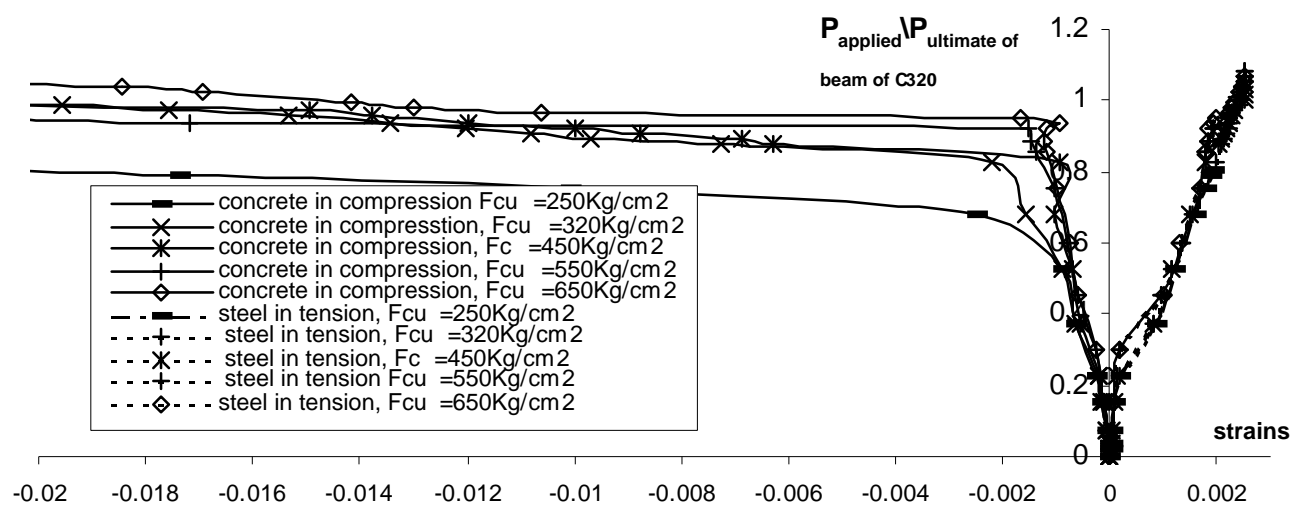

Fig 34) Load central Extreme tensile strain in steel plate and compressive strain in concrete for different values of concrete grades of model $A \quad \mathbf{1 , 1}$

\section{W. R. T Cracking, Yield, and Ultimate Failure Loads:}

Composite beam, which has nail of $3 \mathrm{~mm}$ diameter and concrete strength of 320 $\mathrm{kg} / \mathrm{cm}^{2}$, is used as a control beam. The ratios between cracking load, yield load, and ultimate load of all the analyzed composite -beams to cracking load, yield load, and ultimate load of control composite beam are indicated in Table 3.

Table 3: Summary of theoretical results.

\begin{tabular}{|c|c|c|c|c|c|}
\hline $\begin{array}{c}\text { Beam } \\
\text { Number }\end{array}$ & $\begin{array}{c}\text { Concrete } \\
\text { strength } \\
\mathrm{Kg} / \mathrm{cm}^{2}\end{array}$ & $\begin{array}{c}\text { Nail } \\
\text { diameter } \\
\mathrm{mm}\end{array}$ & $\begin{array}{c}\frac{P_{\text {crack }}}{P_{\text {crckof320 }}} \\
\text { Effect of concrete strength }\end{array}$ & $\frac{P_{\text {yeild }}}{P_{\text {yeildofc320 }}}$ & $\frac{P_{\text {ultimate }}}{P_{\text {ultimateofc320 }}}$ \\
\hline 1 & 250 & 3 & 0.66 & 0.97 & 0.802 \\
\hline 2 & 320 & 3 & 1 & 1 & 1 \\
\hline 3 & 450 & 3 & 1 & 1.05 & 1.045 \\
\hline 4 & 550 & 3 & 2 & 1.13 & 1.08 \\
\hline 5 & 650 & 3 & 2 & 1.13 & 1.08 \\
\hline \multicolumn{7}{|c|}{ Effect of connector diameter } \\
\hline 6 & 320 & 1 & 1 & 1 & 0.89 \\
\hline 7 & 320 & 2 & 1 & 1 & 0.95 \\
\hline 8 & 320 & 4 & 1 & 1 & 1 \\
\hline 9 & 320 & 6 & 1 & 1 & 1 \\
\hline
\end{tabular}


Also Fig. 33 shows variation of these loads with respect to the used concrete grades. From comparing these ratios, it can be seen that, As the concrete compressive strength increases the cracking, the yield and the ultimate loads improved for certain limit ( as the full steel section reaches to its plastic limit).

\section{5-2-Effect of Connector Diameter}

\section{W. R. T Cracking, Yield, and Ultimate Failure Loads and Shape of Failure}

The Summary of theoretical results of the analyzed composite beams is given in Table 3. Also, Fig. 39 shows variation of the ultimate failure load with respect to the used nail diameter. It can be seen form this table, the nail diameter effects on the ultimate failure loads only. Also, Fig. 35 and Fig. 36 show the fracture mechanism of composite beam with $1 \mathrm{~mm}$ diameter. It can be seen form these Figs that, the fracture of the nail, the local buckling and the distortion buckling of the steel plate at center at compression zone. Obviously premature fracture failure in the nail occurs before the composite beam reaches to the ultimate flexural capacity

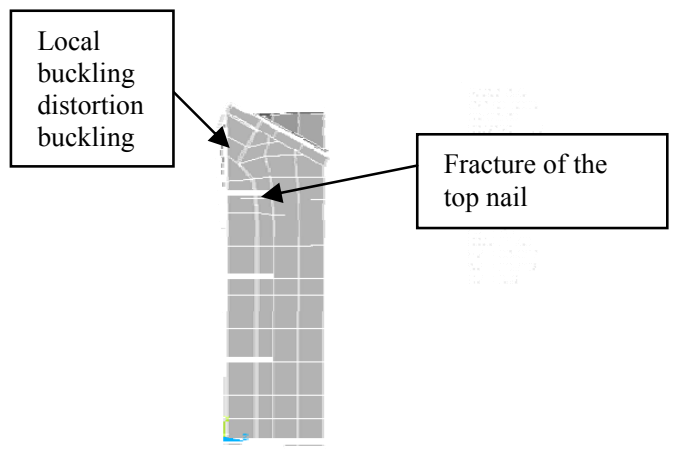

Fig (35) the deformed cross section at failure of the composite beam A1.1 (nail $=1 \mathrm{~mm}$ ) fracture of the center top nail

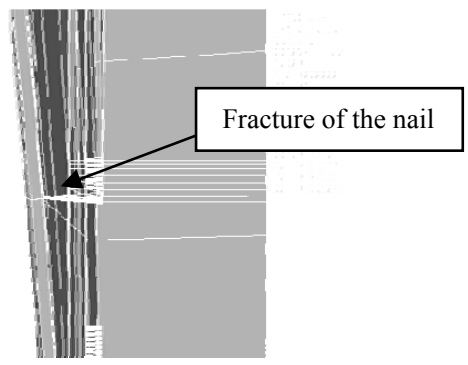

Fig (36) the deformed cross section at failure of the composite beam A1.1 $\left(\mathrm{F}_{\mathrm{cu}}=550 \mathrm{~kg} / \mathrm{cm}^{2}\right)$ fracture of the steel plate at bottom

\section{W. R. T Deflection:}

Load-central deflection curves of the analyzed composite beams of different nail diameter were plotted as shown in Fig. 37. From these curves it can seen that: No effect of nail diameter on the flexural rigidity of the analyzed composite beams.

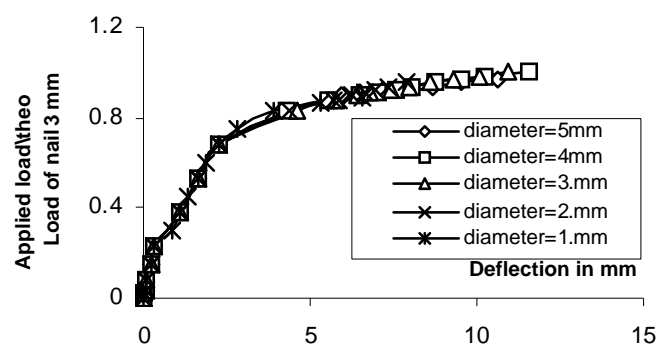

Fig (37) Load central -Deflection of model A1.1 using different nail diameter

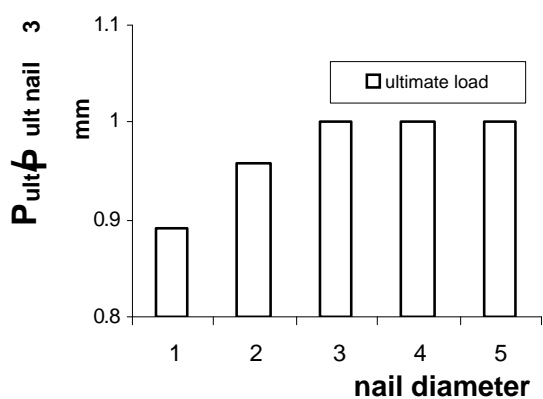

Fig (39) variation in ultimate load of versus nail daimeter 


\section{6- CONCLUSIONS}

1- A numerical study is carried out for cold deformed bi-steel concrete -composite beams using finite elements adopted by ANYSYS. The numerical results show good agreement with the experimental values reported by Ahmed.

2- This numerical modeling helps to track the crack formation and propagation, yielding and buckling of steel plate, crushing of concrete and shearing of connectors..

3- To have the ultimate flexural capacity of the composite section, it is necessary to ensure that the following modes of failure do not occur prematurely: local buckling and lateral distortional buckling of steel component, fracture of shear connectors and failure of concrete of the composite member due to the concentrated loads or dowel loads of shear connectors.

\section{7- REFERENCES}

[1] Ahmed Fathalla Mohamed El-min, "Structural Behavior of Bi-Cold Deformed Steel Concrete Compresite Beams", Civil Eng. Dept., Faculty of Eng., Assuit University, Assuit, Egypt,2005

[2] Zona-A; Barbato-M; Conte-JP "Finite Element Response Sensitivity Analysis of Steel-Concrete Composite Beams with Deformable Shear Connection", Journal -of-Engineering-Mechanics, V 131 n 11 November 2005, P1125-1139.

[3] Lapko-Andrzej; Sadowska-Barbara; Timaszewicz-Andrrze-j; “ Experimental and Numerical Analysis of Flexural Composite Beams with Partial Use of High Strength/ High Performance Concrete"; Journal of Civil Engineering and Management “, v 11 n 2 2005, P115-120.

[4] Jurkiewiez-B; Hottier-JM; "Static Behavior of a Steel - Concrete Composite Beam with an Innovative Horizontal Connection", Journal of Constructional - Steel- Research. v 61 n 9 September 2005, P 1286-1300.

[5] Fragiacomo-M;Amadio-c; Macorini-L; "Finite Element Model for Collapse and Long-Term Analysis of Steel- Concrete Composite Beams", Journal of Structural Engineering, V 130 n 3 March 2004, P 489-497.

[6] Nie-Jianguo; Fan-Jiansheng; Cai-Cs; "Stiffness and Deflection of SteelConcrete Composite Beams Under Negative Bending”, Journal of Structural Engineering, 130 n 3 November 2004, P1842-1851.

[7] Faella-Ciro; Martinell - Enzon; Nigro-Emidio; "Shear Connection Nonlinearity and Deflections of Steel-Concrete Composite Beams: A simplified Method", Journal of Structural Engineering v 129 n1 January 2003, P $12-20$.

[8] Zhou-Lingyu; Yu-zhiwu; jaing-Lizhong;" Coupled Analysis of Slip and Deflection for Continuous Composite Beams of Steel and Concrete", Advances in Structural Engineering. V 7 n3 June 2004, P 257-269.

[9] Bullo-S; DiMaco_R; “ A Simplified Method for Assessing The Ductile Behavior of Stud Connectors in Composite Beams with high Strength Concrete Slab"; Journal of Constructional - Steel- Research v60 n9 September 2004, P 13871408. 
[10] Fabbrocino-G;Manfredi G; Cosenza-E; "Non-Linear Behavior of Continuous Steel Concrete Composite Beams"; Proceedings of the Conference: Composite Construction in steel and Concrete IV Banff, Alta. Canada 2000, P P 237-248.

[11] Egyptian Code of Practice for design and Construction of Reinforced Concrete Structures, No.203, 2001

[12] ANSYS, ANSYS User 's Manual

\section{التحليل الإنشائي للكمرات المزدوجة التركيب من الخرسانة والقطاعات الصلب المشكلة على البارد التركي البرد}

يقدم هذا البحث در اسة تحليلية للسلوك الإنشائي للكمر ات المزدوجة التركيب من الخرسـانة

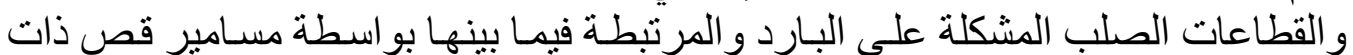

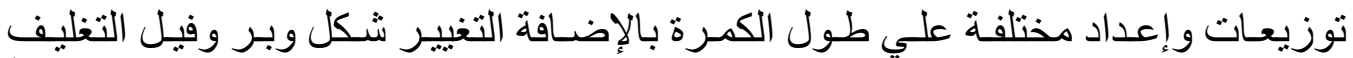

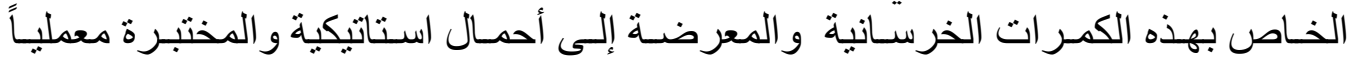

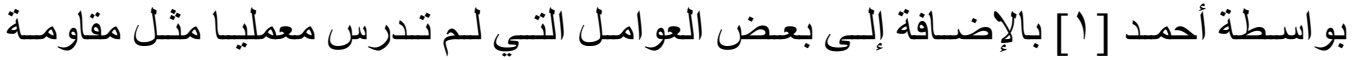

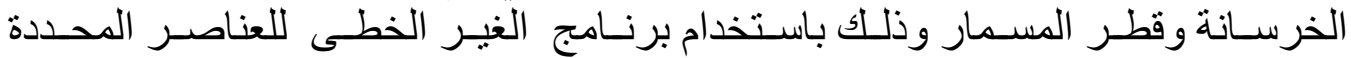
(ANSYS)

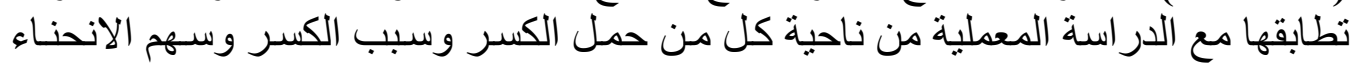

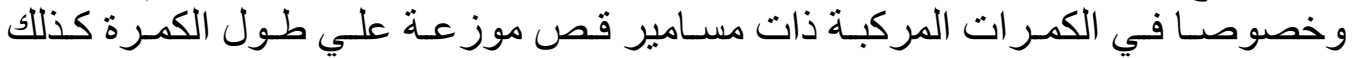

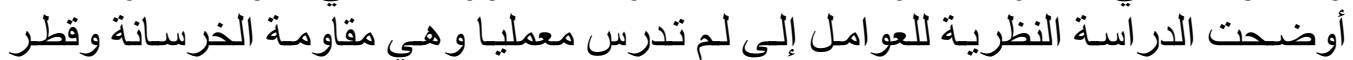

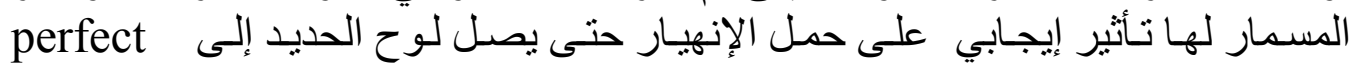
.plastic limit 